\title{
The Postsynaptic Localization of the Glycine Receptor-Associated Protein Gephyrin Is Regulated by the Cytoskeleton
}

\author{
J. Kirscha and H. Betz \\ Department of Neurochemistry, Max-Planck-Institute for Brain Research, 60496 Frankfurt/Main, Federal Republic of \\ Germany
}

\begin{abstract}
The mechanisms underlying the postsynaptic localization of neurotransmitter receptors are poorly understood. Recently, the peripheral membrane protein gephyrin has been shown to be essential for the formation of inhibitory glycine receptor clusters in cultured rat spinal cord neurons. In vitro gephyrin binds with high affinity to polymerized tubulin. Here, the interaction of gephyrin with different components of the cytoskeleton was investigated in primary cultures of rat spinal neurons. After treatment with alkaloids affecting the cytoskeleton, the morphology of postsynaptic gephyrin clusters was analyzed by confocal immunofluorescence microscopy. Depolymerization of microtubules by demecolcine reduced both the percentage of cells with postsynaptic gephyrin clusters and the number of clusters/cell. The size of the remaining gephyrin clusters was increased whereas their gephyrin density was significantly lower than under control conditions. Depolymerization of microfilaments by cytochalasin $D$ in contrast generated smaller clusters of increased gephyrin density. Demecolcine also dispersed postsynaptic glycine receptor clusters as revealed by immunostaining with a specific monoclonal antibody. These findings support the view that in vivo gephyrin anchors receptor polypeptides to the cytoskeleton by a complex interaction with microtubules and microfilaments.
\end{abstract}

[Key words: gephyrin, receptor clustering, glycine receptor, microtubules, microfilaments, cytoskeleton, tubulinbinding protein]

Signal transmission at chemical synapses depends critically on the precise apposition of presynaptic nerve terminals to postsynaptic membrane specializations carrying high densities of the appropriate neurotransmitter receptors. Little is known about the mechanisms, which underlie the formation and maintenance of these highly specialized postsynaptic membrane areas in the CNS. Extracellular as well as intracellular components appear to be required for the postsynaptic accumulation of the nicotinic

\footnotetext{
Received Nov, 10, 1994: accepted Dec. 14, 1994

We thank Drs. H. Rohrer and V. O'Connor for their helpful and critical comments on the manuscript, and Ina Wolters for excellent technical assistance. This work was supported by Deutsche Forschungsgemeinschaft (Schwerpunktprogramm "Funktionelle Domänen" and Leibniz-Programm) and Fonds der Chemischen Industrie.

Correspondence should be addressed to H. Betz, Department of Neurochemistry, Max-Planck-Institute for Brain Research, Deutschordenstraße 46, 60496 Frankfurt/Main, FRG

${ }^{2}$ Present address: Zentrum der Morphologie, Universität Frankfurt, TheodorStern-Kai 7, 60596 Frankfurt/Main, FRG.

Copyright $(\mathcal{C} 1995$ Society for Neuroscience $\quad 0270-6474 / 95 / 154148-09 \$ 05.00 / 0$
}

acetylcholine receptor at the developing motor end plate (McMahan and Wallace, 1989; Froehner, 1991; Rupp et al., 1991). The attachment of receptor polypeptides to cytoskeletal elements is thought to constitute an important mechanism for the regulation of receptor localization (reviewed in Hirokawa, 1991). However, the molecular basis of receptors-cytoskeleton interactions is still poorly understood.

Different lines of evidence implicate the peripheral membrane protein gephyrin (Schmitt et al., 1987; Prior et al., 1992) in the formation of postsynaptic glycine receptor (GlyR) clusters. Gephyrin copurifies with the transmembrane subunits of the inhibitory GlyR upon affinity chromatography (Pfeiffer et al., 1982) and can be extracted from spinal cord membranes by alkaline treatment (Schmitt et al., 1987). Electron microscopical studies have demonstrated the presence of gephyrin at the cytoplasmic face of glycinergic synapses (Triller et al., 1985, 1987; Altschuler et al., 1986), and denervation has been shown to affect this postsynaptic localization (Seitanidou et al., 1992). In vitro gephyrin binds with high affinity to polymerized tubulin (Kirsch et al., 1991), and therefore this peripheral membrane protein qualifies as putative linker between receptors and the cytoskel eton.

cDNA cloning revealed that the gephyrin mRNA exists in several splice variants, which differ by four short nucleotide sequences at the $5^{\prime}$ end of the coding region (Prior et al., 1992). Recent in situ hybridization (Kirsch et al., 1993a) and immunohistochemical (Kirsch and Betz, 1993) data indicate a widespread expression of gephyrin throughout the CNS. Interestingly, its distribution is not restricted to brain regions expressing the known GlyR isoforms (Malosio et al., 1991); therefore, gephyrin may also be associated with other neurotransmitter receptors. Indeed, gephyrin immunoreactivity has been demonstrated at GABAergic synapses in the inner plexiform layer of the rat retina (Sassoè-Pognetto et al., 1995). In cultivated spinal neurons, the accumulation of géphyrin at differentiating postsynaptic membrane specializations precedes clustering of the GlyR (Kirsch et al., 1993b). Moreover, inhibition of gephyrin expression by antisense oligonucleotides prevents the formation of GlyR clusters in these cultures, indicating that gephyrin is indeed essential for the postsynaptic localization of this receptor (Kirsch et al., 1993b).

To investigate whether gephyrin is linked to cytoskeletal elements in vivo, cultured spinal neurons were treated with drugs affecting the organization of neuronal microtubules and microfilaments. Quantitative immunocytochemical evaluation of the treated cells revealed drastic changes in the number and size of gephyrin clusters after disruption of microfilaments or microtu- 

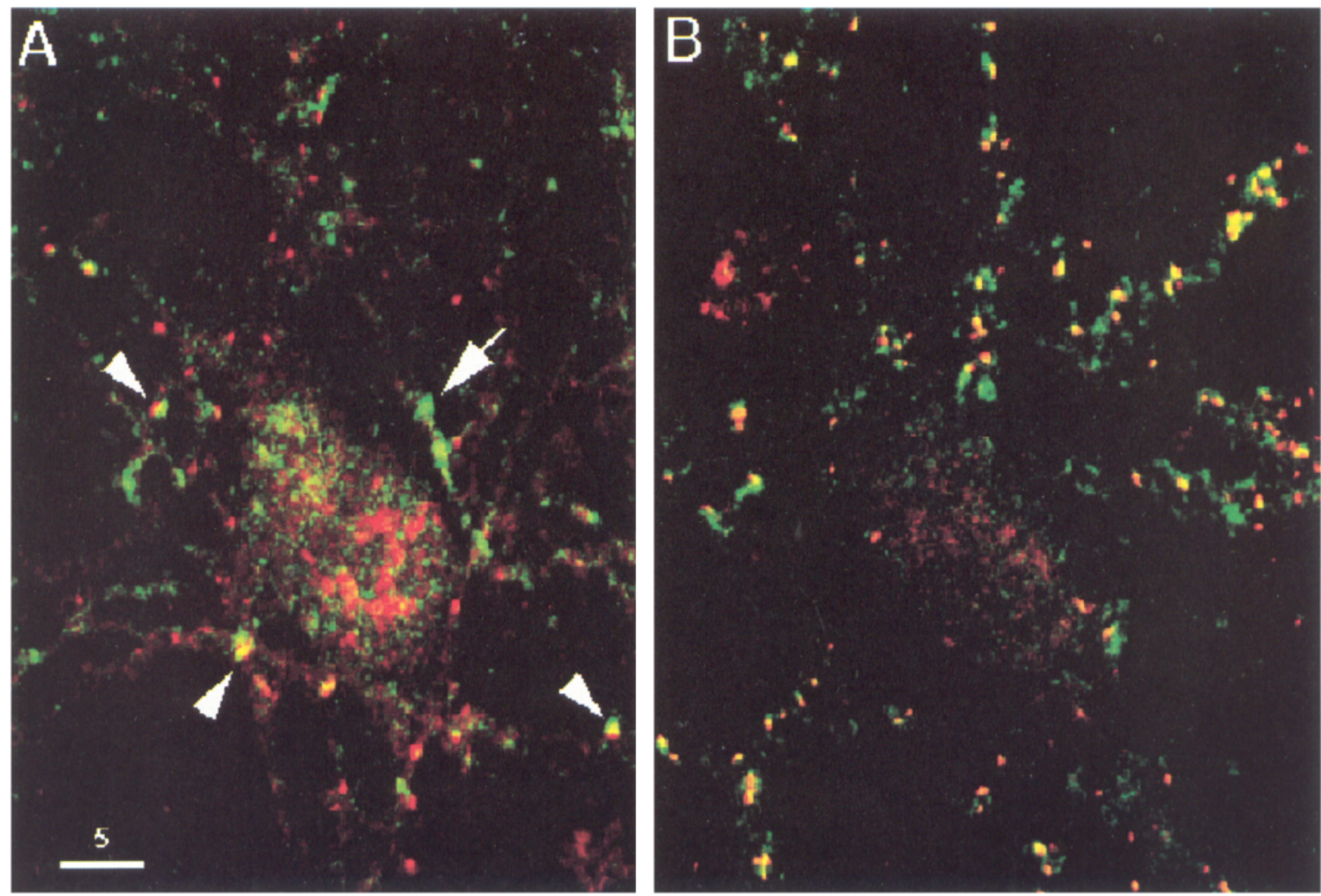

Figure 1. Localization of gephyrin and synaptic vesicle antigens in spinal neurons. Spinal cord cultures were immunostained with mAb 7a (red) and a polyclonal anti-synaptic vesicle antiserum (green) at days $6(A)$ and $10(B)$ in vitro. Confocal images represent single optical sections. A, At day 5 in vitro the immunoreactivities of gephyrin (red) and synaptic vesicle proteins (green) do not overlap. Only a few gephyrin clusters are, at this stage, apposed to or colocalized with presynaptic terminals (yellow; arrowheads). Enhanced concentrations of synaptic vesicle proteins are visible along some neuritic profiles (arrow). B. At day 10 of in vitro development, most of the gephyrin clusters colocalize with synaptic vesicle proteins (yellow dots). Bar, $5 \mu \mathrm{m}$.

bules, respectively. Our data suggest an antagonistic action of both filament systems on the organization of glycinergic postsynaptic membrane specializations.

\section{Materials and Methods}

Tissue culture. The preparation of embryonic spinal cord cultures was similar to previously used protocols (Hoch et al., 1990; Nicola et al., 1992; Kirsch et al., 1993b). Briefly, spinal cords were removed from Wistar rat embryos at day 14 after gestation (E14), coarsely dissected in PBS supplemented with $33 \mathrm{~mm}$ glucose, and subsequently dissociated by gentle trituration. After centrifugation for $10 \mathrm{~min}$ at $120 \times \mathrm{g}$, the cells were resuspended in a 1:1 mixture of Ham F12:DMEM (Gibco) supplemented with $5 \mathrm{~mm}$ HEPES, pH 7.4, $33 \mathrm{~mm}$ glucose, $2 \mathrm{~mm}$ glutamine, $20 \mathrm{~mm} \mathrm{NaHCO}, 25 \mu \mathrm{g} / \mathrm{ml}$ insulin, $100 \mu \mathrm{g} / \mathrm{ml}$ transferrin, 20 nM progesterone, $60 \mathrm{~mm}$ putrescine, $30 \mathrm{~nm}$ selenium, $0.1 \%(\mathrm{w}: \mathrm{v})$ ovalbumin, $5 \mathrm{U} / \mathrm{ml}$ penicillin, and $5 \mu \mathrm{g} / \mathrm{ml}$ streptomycin (all supplements were purchased from Sigma). The cells were plated in a 24-well cluster (Costar) onto poly-L-lysine (Sigma)-coated coverslips (Menzel, No. 1, $14 \mathrm{~mm}$ aa) in a volume of $300 \mu \mathrm{l} / \mathrm{well}$ and at a density of 120,000 cells/well. The cultivated neurons were kept in a humidified atmosphere of $95 \%$ air $/ 5 \% \mathrm{CO}_{2}$ at $37^{\circ} \mathrm{C}$ for up to 2 weeks. At day 3 in vitro, the culture consisted of approximately $90 \%$ neurons as judged by immunolabeling with mAbs specific for the neuron-specific protein MAP2 (Kirsch et al., 1990). The other cells were mostly glia and fibroblasts, as judged by labeling with antibodies against glial fibrillary acidic protein and vimentin (data not shown). The number of non-neuronal cells increased to about $50 \%$ at day 10 in vitro.
Alkaloid treatment. Unless stated otherwise, drugs which modify the organization of the cytoskeleton were added to 10-d-old spinal cord cultures $3 \mathrm{hr}$ prior to fixation. Cytochalasin D, demecolcine, nocodazole, and $\gamma$-lumicolchicine (all purchased from Sigma) were used at final concentrations of $10 \mu \mathrm{g} / \mathrm{ml}$ (cytochalasin D, nocodazole, $\gamma$-lumicolchicine) and $5 \mu \mathrm{g} / \mathrm{ml}$ (demecolcine, $\gamma$-lumicolchicine), respectively. Taxol, generously supplied by the Drug Synthesis and Chemistry Branch, Division of Cancer Treatment, National Cancer Institute (Bethesda, MD), was added from a dimethyl sulfoxide stock solution to a final concentration of $1 \mu \mathrm{g} / \mathrm{ml}$. Control cultures received the same volume of drug solvent only.

Antibodies. MAb 4a specific for the GlyR $\alpha$ and $\beta$ subunits and mAb 7a specific for gephyrin have been characterized previously (Pfeiffer et al., 1984; Becker et al., 1989; Schröder et al., 1991; Kirsch and Betz, 1993). The mAbs were purified from hybridoma supernatants by protein A affinity chromatography and used at a dilution of 1:500 in PBS. A polyclonal antiserum against synaptic vesicle proteins was kindly provided by Dr. P. Knaus. This antiserum detects the synaptic vesicle proteins synaptophysin and, to a lesser extent, synaptoporin on Western blots (Knaus et al., 1986, 1990). For immunocytochemistry, the serum was used at a dilution of 1:500 in PBS. MAb DM1A specific for $\alpha$-tubulin, anti-vimentin, and anti-GFAP were purchased from Sigma and used at a dilution of 1:500. FITC-conjugated goat anti-rabbit IgG and carboxymethylindoylcyanine 3 (Cy 3)-coupled goat anti-mouse IgG $\mathrm{F}\left(\mathrm{ab}^{\prime}\right)_{2}$ (Dianova, Hamburg, FRG) were employed as secondary antibodies (dilution 1:1000).

Immunofluorescence. The cultivated spinal neurons were processed for immunofluorescence as described previously (Kirsch et al., 1990, 

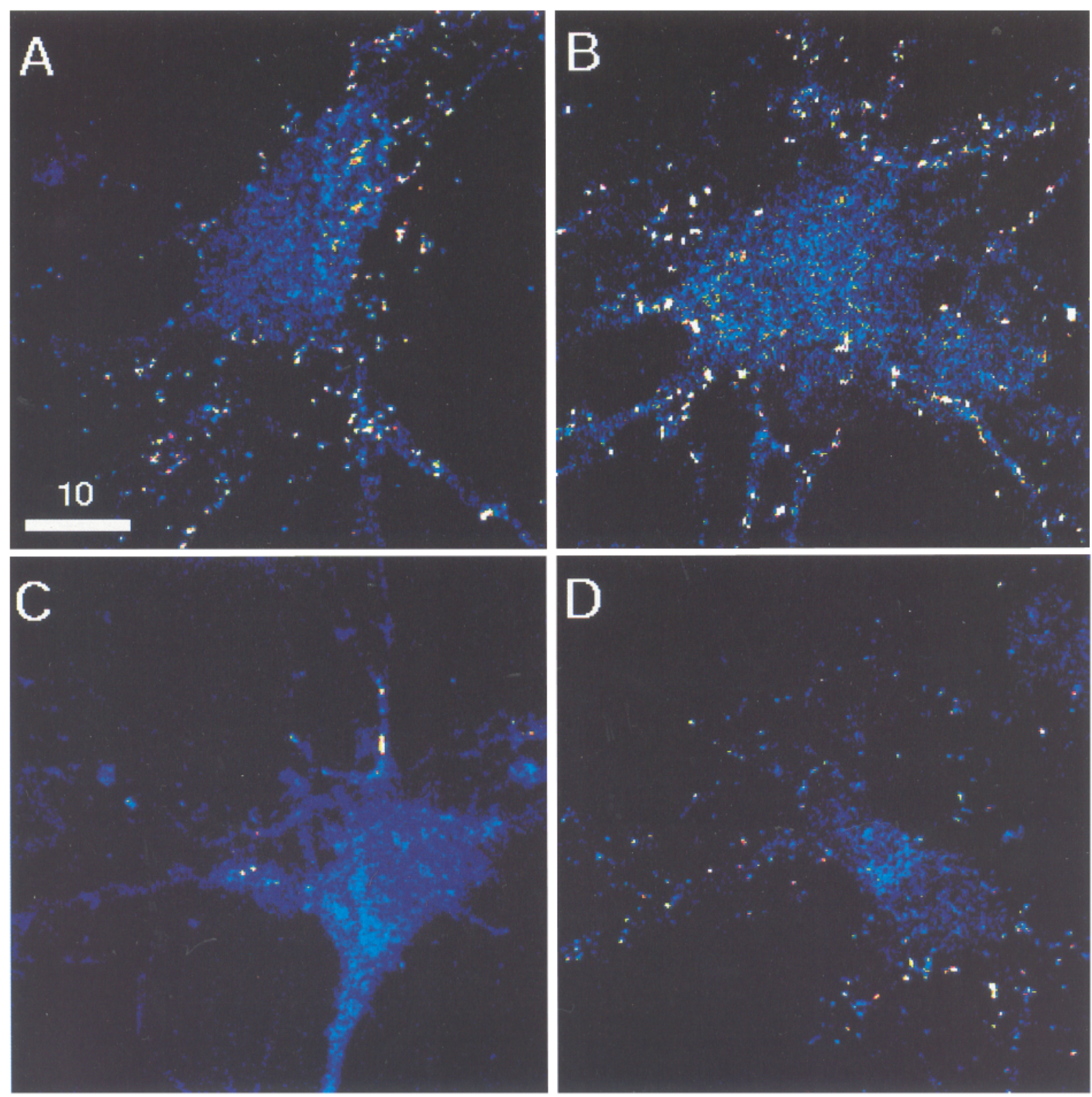

Figure 2. Effects of alkaloid treatment on gephyrin clusters. Spinal neurons at day 10 in vitro were cultured under control conditions $(A)$ or treated with taxol $(B)$, demecolcine $(C)$, and cytochalasin D $(D)$ for $3 \mathrm{hr}$. After fixation the cells were immunoreacted with mAb 7a to visualize gephyrin. Representative confocal sections are displayed in pseudocolor coding. A, Under control conditions many gephyrin clusters are visible at the periphery of the cell soma and along neurites. Some residual cytoplasmic immunoreactivity is visible. $B$, Treatment with taxol does not induce changes in the display of gephyrin clusters. $C$, Demecolcin treatment eliminates most gephyrin clusters. $D$, After treatment with cytochalasin $\mathrm{D}$, gephyrin clusters appear smaller. Bar, $10 \mu \mathrm{m}$.

1993b). For the simultaneous detection of synaptic vesicle proteins and gephyrin, the procedure was performed using a mixture of both mAb $7 \mathrm{a}$ and the polyclonal synaptic vesicle antiserum during the first incubation, and a mixture of anti-mouse and anti-rabbit antibodies for the second incubation. Double labeling with two mAbs was carried out as described (Triller et al., 1987), performing an additional blocking step with unconjugated anti-mouse IgG (Dianova, Hamburg, FRG) after the incubation with the first secondary antibody. Appropriate controls in the absence of primary antibodies confirmed the specificity of the immunolabeling. F-actin was visualized with FITC-labeled phalloidin (Sigma; dilution, 1:50) as described (Wulf et al., 1979).

Confocal microscopy. Optical sections with a pixel size of $0.1 \mu \mathrm{m}^{2}$ were recorded using a Sarastro 2000 confocal microscope (Molecular Dynamics). A Gaussian filter with $3 \times 3 \times 3$ kernel size was applied to the primary data to eliminate statistical noise. All data were displayed employing a linear look-up table. In double-labeling experiments, both fluorescence channels were recorded simultaneously, and the signals were compared at the level of single optical sections. For semiquantitative analysis of gephyrin clusters, all data were acquired under identical conditions for signal amplification utilizing the whole range of 256 intensity values, with peak intensities adjusted to maximal values. Thus, one relative fluorescence unit ("arbitrary unit") corresponds to $1 / 256$ of the peak intensity. Cluster size and mean fluorescence intensities were determined from single optical sections using IMAGESPACE software (Molecular Dynamics, Sunnyvale, CA).

Quantitation. After alkaloid treatment and routine immunofluorescence procedures, neurons with gephyrin clusters were counted from five randomly selected fields (approximately 100 cells/field) using a Zeiss Axiophot equipped with a $40 \times 1.3$ Planapochromat. Means and standard deviations (SD) of three independent determinations were calculated. Similarly, the mean number of clusters/cell $( \pm$ SD) were calculated from 10 single determinations/assay. Means and standard errors 
of the mean (SEM) were calculated from measurements obtained from confocal optical sections. Gephyrin density was defined as mAb 7a fluorescence intensity per $\mu \mathrm{m}^{2}$ cluster area for each individual cluster The statistical significance of the data was evaluated by $t$ test.

\section{Results}

In primary cultures prepared from embryonic rat spinal cord (E14), gephyrin is expressed in neurons and localized in "hot spots" near the cell periphery and in neuritic extensions. Double immunolabeling with mAbs specific for gephyrin and GlyR polypeptides has shown that after day 10 in vitro nearly all of the "hot spots" which are immunoreactive for gephyrin also contain GlyR polypeptides (Kirsch et al., 1993b). To investigate whether these gephyrin/GlyR clusters are apposed to presynaptic terminals, and thus equivalent to glycinergic postsynaptic membrane specializations, spinal neurons were double labeled with a monoclonal antibody (mAb 7a) specific for gephyrin and a polyclonal antiserum generated against synaptic vesicle proteins (see Materials and Methods). Evaluation of simultaneously scanned confocal sections $(0.1 \mu \mathrm{m}$ depth) showed that at early stages of in vitro development, these antigens are found at different locations (Fig. 1A). At day 6 in vitro, gephyrin immunoreactivity was seen at sites of focal cell attachment, in the periphery of neuronal somata, and as fluorescent dots along the neurites. In contrast, synaptic vesicle proteins were detected as diffuse label in the cytoplasm and in neurites. However, by day 10 in vitro most of the gephyrin clusters were apposed to or colocalized with punctate structures containing high local concentrations of synaptic vesicle proteins (Fig. 1B). The latter are known to correspond to presynaptic terminals (Fletcher et al., 1991). Similar results were obtained with mAb $4 a$ (data not shown and see Fig. 4A), an antibody specific for GlyR $\alpha$ and, to a lesser extent, $\beta$ subunits (Pfeiffer et al., 1984; Kirsch and Betz, 1993). These observations are consistent with previous electrophysiological data on synaptogenesis in such cultures (Ransom et al., 1977) and show that spinal neurons form biochemically "mature" synaptic contacts after $10 \mathrm{~d}$ in vitro. These synapses can be identified by standard immunocytochemical criteria and are characterized by high densities of gephyrin and GlyR polypeptides accumulating at the differentiating postsynaptic membrane.

To investigate whether the cytoskeleton is involved in the organization of these clusters, 10-d-old cultures from rat spinal cord were treated for $3 \mathrm{hr}$ with drugs affecting different cytoskeletal elements. The alkaloid taxol was used to stabilize microtubules, and demecolcine or cytochalasin D were employed to disrupt microtubules or microfilaments, respectively. The effects of drug treatment were then monitored by immunolabeling of the respective filament system using either a mAb directed against tubulin or FITC-conjugated phalloidin. As expected from previous studies, treatment with taxol resulted in the formation of microtubular asters in fibroblast-like cells without appreciably altering the microtubular cytoskeleton in neurons (data not shown). In contrast, short time treatment with demecolcine or cytochalasin depolymerized neuronal microtubules or cortical microfilaments, respectively, without affecting other cytoskeletal structures or altering the general cell morphology. These results are in line with a large number of previous reports on the effects of these alkaloids on the organization of the neuronal cytoskeleton (Miranda et al., 1974; Schiff and Horwitz, 1980; Bencherif and Lukas, 1993; Fan et al., 1993; Fentie and Roisen, 1993; Rosenmund and Westbrook, 1993; Bassell et al., 1994; Meade
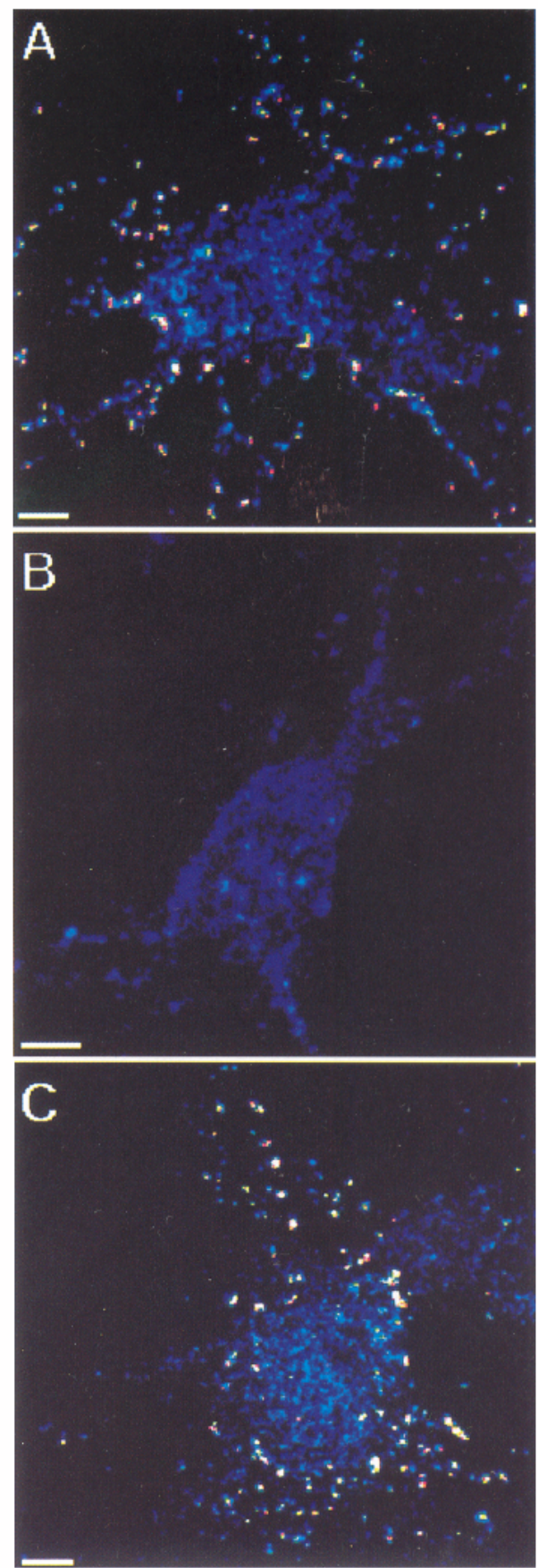

Figure 3. Effects of nocodazole and $\gamma$-lumicolchicine on gephyrin clusters. Spinal neurons at day 10 in vitro were cultured under control conditions $(A)$ or treated with nocodazole $(B)$ and $\gamma$-lumicolchicine $(C)$ for $3 \mathrm{hr}$. After fixation the cells were immunoreacted with mAb $7 \mathrm{a}$ to visualize gephyrin. Representative confocal sections are displayed in pseudocolor coding. $A$, In untreated neurons many gephyrin clusters are visible at the periphery of the cell soma and along neurites. $B$, Treatment with nocodazole eliminates most gephyrin clusters; this is comparable to the changes seen after demecolcine treatment (see Fig. 2C). $C$, Gephyrin clusters are maintained after $\gamma$-lumicolchicine treatment.

and Topp, 1994). Treatment of the cultures with $\gamma$-lumicolchicine, an inactive isomer of colchicine, did not affect the organization of the microtubular cytoskeleton as monitored by $\alpha$-tubulin immunolabeling (data not shown).

Concomitant with the aforementioned alterations of cytoskel- 

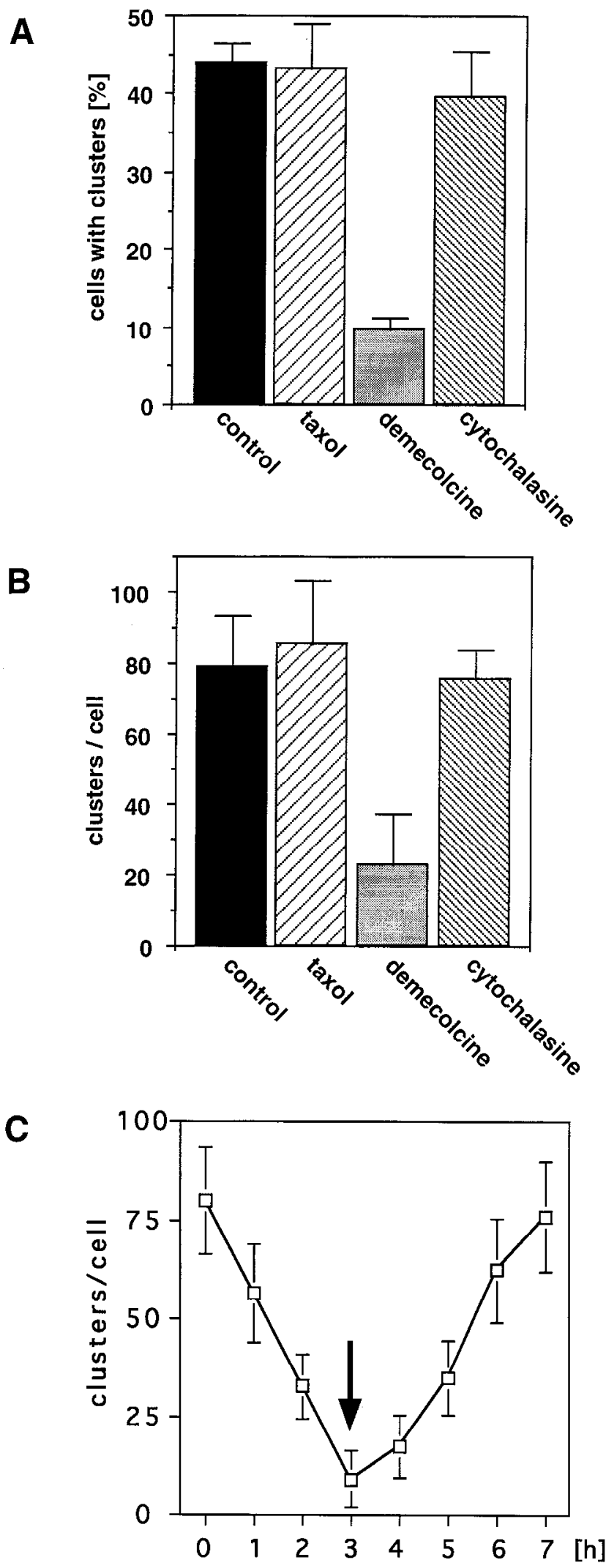

Figure 4. Quantitative evaluation of the effects of alkaloid treatment Primary spinal cord cultures at day 10 in vitro were kept under control conditions or treated with taxol, demecolcine, or cytochalasin D and immunoreacted with $\mathrm{mAb} 7 \mathrm{a}$ to visualize gephyrin clusters. $A$, Cells with gephyrin clusters were counted in five randomly selected fields (approximately 100 cells/field). The bars show means \pm SD from three etal organization, the following changes in mAb 7a immunoreactive gephyrin clusters were noted upon drug treatment (Fig. 2). Whereas under control conditions (Fig. 2A) and after incubation with taxol (Fig. 2B) many gephyrin clusters were found in the periphery of the neuronal soma and along the neurites, neurons treated with demecolcine displayed a much lower number of gephyrin clusters (Fig. 2C). The number of gephyrin clusters in cytochalasin D-treated cells was similar to that of control neurons; their size, however, appeared to be significantly smaller (Fig. 2D). $\Lambda$ loss of gephyrin clusters was also obscrved after treatment of the cultures with nocodazole, another microtubuledisrupting drug, but was not seen in cultures treated with $\gamma$-lumicolchicine (Fig. 3). A decrease in the number of clusters/cell was also observed when 6-d-old cultures were treated with demecolcine; the total number of clusters seen at this early stage was much lower, however.

Quantitative analysis of the immunocylochernical data showed that demecolcine treatment led to a drastic decrease in both the number of cells with detectable clusters and the mean number of clusters/cell (Fig. 4). Only 9\% of the cells in these cultures had clusters, as opposed to about $40 \%$ under control conditions or after treatment with taxol or cytochalasin D (Fig. $4 A$ ). Moreover, the number of clusters/cell was also significantly reduced after demecolcine treatment from 80 to about 20 (Fig. $4 B$ ). The effect of demecolcine could be reversed within $4 \mathrm{hr}$ after removal of the drug from the culture medium (Fig. 4C), with the numbers of clusters/cell reaching values indistinguishable from those found before the alkaloid treatment (Fig. 4C). We infer from these data that an intact microtubular cytoskeleton is essential for the stabilization of postsynaptic gephyrin clusters.

lo analyze the drug effects at the level of individual gephyrin clusters, several confocal sections of spinal neurons were evaluated. The mean intensity of immunolabeling with $\mathrm{mAb} 7 \mathrm{a}$, which correlates to the gephyrin content, and the size of 799 individual clusters was determined from confocal optical sections. The results are summarized in Table 1. The mean fluorescence intensity of the individual clusters varied only slightly after the treatment with alkaloids. On a linear scale from 0 to 256 units, the mean intensity ranged from 150 units in control to 119 units in cytochalasin D-treated cultures. However, the mean cluster size of demecolcine- and cytochalasin D-treated neurons differed significantly $(p>0.9995)$ from that of control and/or taxol-treated cells. Whereas the mean cluster size under control conditions and after taxol treatment ranged between 0.27 and $0.28 \mu \mathrm{m}^{2}$, the disintegration of actin filaments by cytochalasin $\mathrm{D}$ reduced this value to $0.16 \mu \mathrm{m}^{2}$. In contrast, the clusters detectable after demecolcine showed an increased mean size of $0.37 \mu \mathrm{m}^{2}$ (Table 1). Interestingly, under none of these experi-

\section{$\leftarrow$}

independent experiments. $B$, To determine lite number of clusters/cell all immunoreactive spots on 10 randomly selected cells were counted. The data represent means \pm SD. Note the decrease in the percentage of cells with clusters $(A)$ and the number of clusters/cell $(B)$ after demecolcine treatment. $C$, Time course of the disruption of gephyrin clusters and recovery after demecolcine withdrawal. Primary spinal cord cultures at day 10 in vitro were treated with demecolcine as described in Materials and Methods. At the time points indicated, aliquots of the cells were fixed and immunoreacted with $\mathrm{mAb}$ 7a to visualize gephyrin aggregates. To determine the number of clusters/cells, 100 neurons were evaluated/time point. The data represent means \pm SD. After 3 hr of demecolcine treatment, the culture medium was replaced by fresh me dium without demecolcine (arrow) and the reappearance of gephyrin clusters was monitored as described before. 
Table 1. Properties of gephyrin clusters in control and alkaloid-treated cultures

\begin{tabular}{|c|c|c|c|c|}
\hline Culture condition & $\begin{array}{l}\text { No. of } \\
\text { clusters } \\
\text { analyzcd }\end{array}$ & $\begin{array}{l}\mathrm{mAb} 7 \mathrm{a} \\
\text { fluorescence } \\
\text { intensity } \\
\text { [units/clustcr] }\end{array}$ & $\begin{array}{l}\text { Cluster size } \\
{\left[\mu \mathrm{m}^{\prime}\right]}\end{array}$ & $\begin{array}{l}\text { mAb } 7 \mathrm{a} \\
\text { fluorescence } \\
\text { density } \\
{\left[\text { units } / \mu \mathrm{m}^{\prime}\right]}\end{array}$ \\
\hline Control & 168 & $150.2 \pm 2.1$ & $0.28 \pm 0.01$ & $624 \pm 20$ \\
\hline Taxol & 185 & $139.5 \pm 2.3$ & $0.29 \pm 0.01$ & $635 \pm 35$ \\
\hline Demecolcin & 186 & $120.7 \pm 2.4$ & $0.38 \pm 0.01$ & $397 \pm 15$ \\
\hline Cytochalasin D & 260 & $119.2+2.2$ & $0.16+0.005$ & $1121+23$ \\
\hline
\end{tabular}

Spinal cord cultures were treated with the alkaloids at day 10 in vitro for $3 \mathrm{hr}$. After immunostaining the number of immunoreactive clusters, their size and fluorescence intensity were determined in individual optical sections as described in Materials and Methods. Values represent means \pm SEM of three independent experiments. Statistically significant differences to control values as indicated by $t$ test $(p>0.0005)$ are indicated by bold numerals.

mental conditions did the size of the clusters correlate with their fluorescence intensity (correlation coefficients ranged between 0.16 and 0.47 ), indicating that the size of a cluster is independent of its gephyrin content. These results suggest that both microtubules and microfilaments are implicated in the spatial organization of postsynaptic gephyrin clusters. The roles of these filaments, however, appear to be antagonistic.

To further corroborate this conclusion, we calculated the mAb 7 a fluorescence density of the individual clusters, which correlates with the packing density of gephyrin within a cluster. A mean fluorescence density of 624 and $635 \mathrm{units} / \mu \mathrm{m}^{2}$ was found in clusters of control and taxol-treated cells. The mean density in clusters of demecolcine-treated neurons was reduced to 397 units $/ \mu \mathrm{m}^{2}$. Disruption of microfilaments, on the other hand, led to an increase of the mean density to $1121 \mathrm{units} / \mu \mathrm{m}^{2}$ (Table 1 ). We conclude that intact microtubules generate a high gephyrin packing density in postsynaptic clusters and that microfilaments partially counterbalance this action.

To analyze whether the changes in the organization of postsynaptic gephyrin clusters induced by the alkaloid treatment also affect the synaptic localization of GlyR polypeptides, we performed a series of double-labeling experiments with either mAbs $7 \mathrm{a}$ and $4 \mathrm{a}$ or with $\mathrm{mAb} 4 \mathrm{a}$ and an antiserum against synaptic vesicle antigens. This showed that the colocalization at the cell membrane of GlyR polypeptides and gephyrin (Kirsch et al., 1993b) was preserved upon treatment of the cultures with any of these alkaloids (not shown). GlyR immunoreactivity as revealed by $\mathrm{mAb} 4 \mathrm{a}$ was found both intracellularly, presumably at sites of synthesis and post-translational processing, and at the cell surface in peripheral clusters (Nicola et al., 1992; Kirsch et al., 1993b). At day 10 in vitro, these GlyR clusters were either apposed to or colocalized with presynaptic terminals visualized by immunolabeling of synaptic vesicle antigens (Fig. 5A). These findings are consistent with and extend our data shown in Figure 1B. Taxol and cytochalasin treatment did not affect the apposition of GlyR immunoreactivity to presynaptic terminals (not shown). However, the patterns of GlyR immunoreactivity and synaptic vesicle antigens differed strikingly in demecolcinetreated spinal neurons. Here, only a few GlyR clusters colocalized with presynaptic vesicle staining. Moreover, under these conditions most of the GlyR immunoreactivity appeared as a relatively diffuse, ring-shaped labeling of the neuronal membrane, whereas the focal appearance of synaptic vesicle antigens was conserved (Fig. 5B). These data are consistent with the view that demecolcine increases the lateral mobility of the GlyR in the postsynaptic membrane which in untreated cells is restricted by interactions with microtubules.

\section{Discussion}

The data presented in this study indicate that: (1) gephyrin interacts in vivo with components of the cytoskeleton; (2) microtubules and microfilaments have antagonistic effects on the packing density of gephyrin at postsynaptic membrane specializations; and (3) the lateral mobility of the inhibitory GlyR is restricted at postsynaptic sites by an interaction with microtubules.

The most striking result of our investigation is the drastic reduction of gephyrin cluster number after destruction of the neuronal microtubules by demecolcine or nocodazole treatment. This finding suggests that in vivo gephyrin could indeed act as a bivalent linker protein which connects the transmembrane subunits of the GlyR with underlying microtubules (Kirsch et al., $1991,1993 b)$. Although we cannot entirely exclude indirect effects of the alkaloid treatment, our investigations are in agreement with biochemical experiments which demonstrate high-affinity binding of gephyrin to both polymerized tubulin (Kirsch et al., 1991) and the GlyR $\beta$ subunit (Meyer et al., 1994). In addition, demecolcine treatment also affected the size and density of individual gephyrin clusters. Notably, the size of the clusters remaining after the destruction of microtubules was significantly increased, but their fluorescence density was reduced (see Table 1). Double immunolabeling with mAb $4 a$ and $7 \mathrm{a}$ or $\mathrm{mAb}$ $4 \mathrm{a}$ and the antiserum against synaptic vesicle antigens (not shown and Fig. 5) revealed that these effects also apply to postsynaptic GlyRs. In fact, GlyR immunoreactivity codistributed with gephyrin immunoreactivity at the cell membrane under all experimental conditions analyzed, indicating that the gephyrin/ GlyR complex (Schmitt et al., 1987) did not dissociate during the treatment with any of the alkaloids used. The changes observed after demecolcine treatment are consistent with the assumption that the destruction of microtubules increases the lateral mobility of the gephyrin/GlyR complex in the plasma membrane. This "spreading" could then be detected as clusters of increased size and reduced fluorescence intensity (Table 1). Ultimately, the dissociation of the postsynaptic clusters was visualized as diffuse $\mathrm{mAb} 4 \mathrm{a}$ immunolabeling of the cell membrane (Fig. $5 B$ ). In contrast, stabilizing neuronal microtubules by taxol did not affect the size or packing of gephyrin clusters. Presumably, this reflects low amounts of free tubulin in the neuronal cytoplasm. Alternatively, all receptor-bound gephyrin may be saturated with polymerized tubulin.

Surprisingly, treatment of neurons with cytochalasin D left the number of clusters and their gephyrin content unchanged (Fig. 4) but rendered the clusters significantly smaller. Moreover, the 

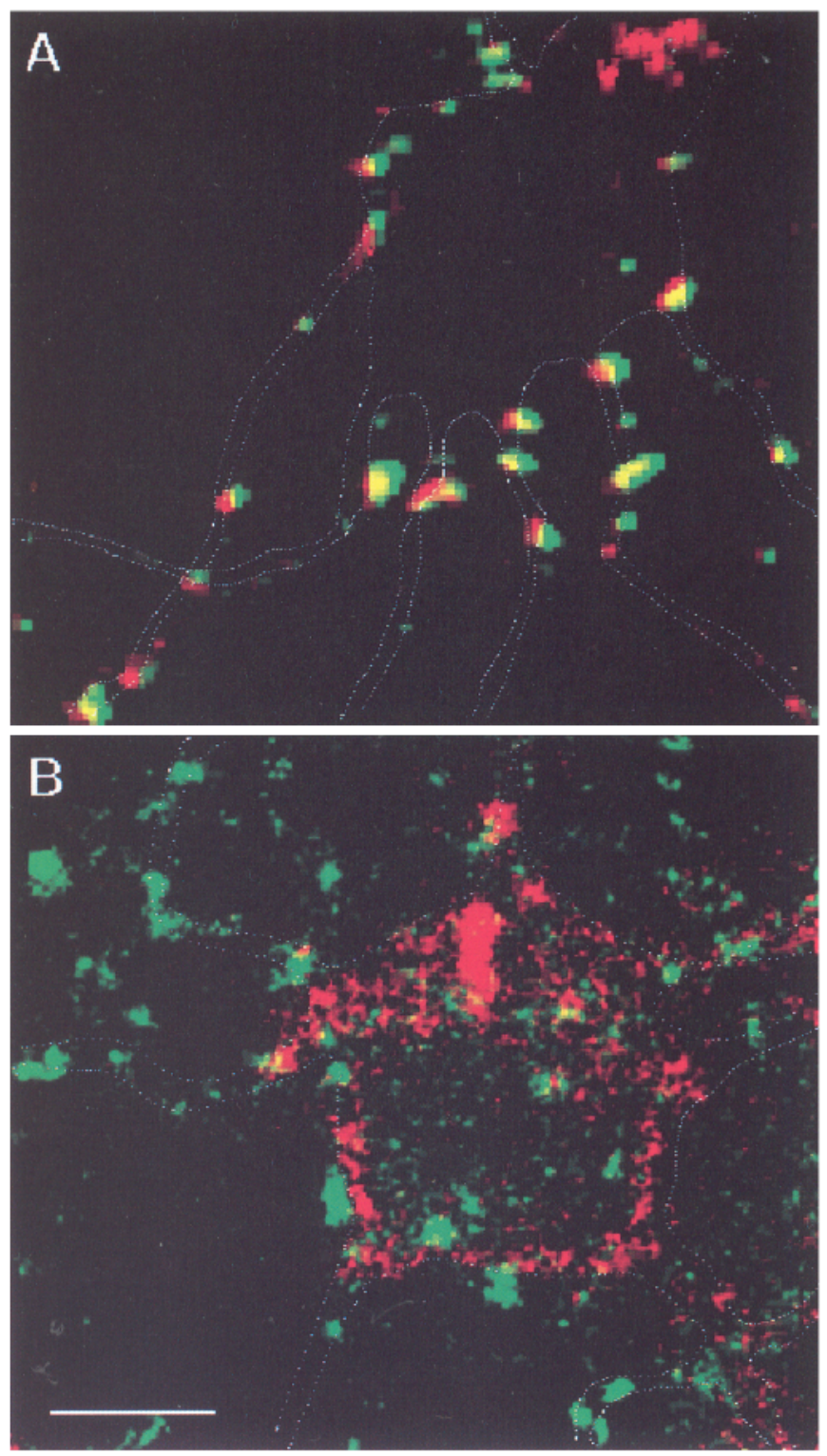

Figure 5. Effect of demecolcine treatment on the distribution of GlyR immunoreactivity. Spinal cord cultures were immunostained with mAb 4a (red) and a polyclonal anti-synaptic vesicle antiserum (green) at day 10 in vitro and analyzed by confocal microscopy. $A$, In control cultures GlyR immunoreactivity (red) is detected both in peripheral clusters and to some extent in the neuronal somata. Immunoreactive GlyR clusters are apposed to structures containing synaptic vesicle antigens, as revealed by yellow dots indicating an overlap of both antigens. B, After demecolcine treatment, GlyR immunoreactivity is diffuse and apparently lines the cell contours, whereas synaptic vesicle immunoreactivity retains a spotted appearance. Dotted lines indicate the cell contours. Bars, $5 \mu \mathrm{m}$.

packing density of gephyrin within individual clusters was significantly higher in cytochalasin D-treated cells than under control conditions. These data introduce microfilaments as additional regulatory elements of cluster organization. Apparently microfilaments reduce the packing of gephyrin in the postsynaptic membrane, and thus counterbalance the condensing effect of microtubules.

A model in which the antagonistic actions of microtubules and microfilaments are rationalized is displayed in Figure 6. According to this model, gephyrin binds directly to both tubulin

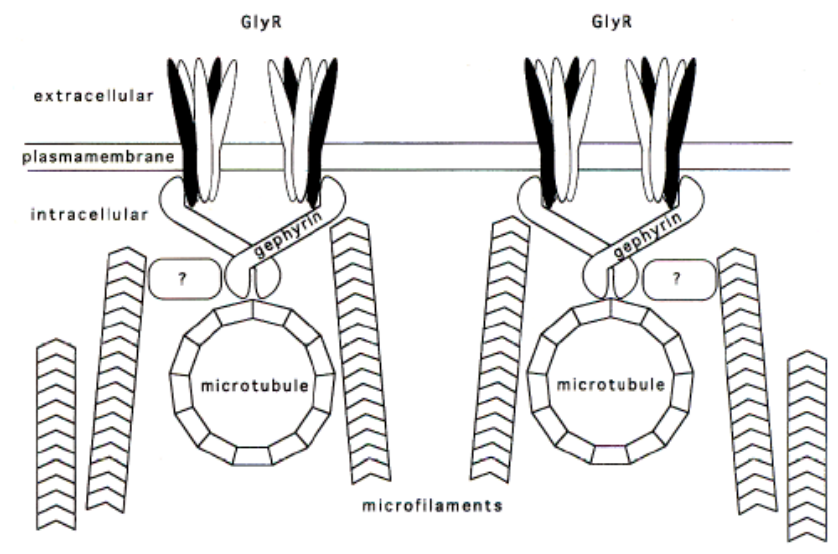

Figure 6. Model of the interactions of gephyrin with the GlyR and the subsynaptic cytoskeleton. Gephyrin anchors the postsynaptic GlyR to microtubules forming a subsynaptic lattice. The interactions with microfilaments could either be direct (center) or involve an additional regulatory actin-binding protein(s) (indicated by a question mark). For

and GlyR subunits, thus forming a subsynaptic lattice of gephyrin and microtubules. Lateral interactions of the gephyrin lattice with microfilaments could be either direct by binding of gephyrin to actin or indirectly mediated by an actin-binding protein of the spectrin type. In both cases, depolymerization of microtubules should lead to a collapse of the gephyrin lattice, and consequently to a increased lateral mobility of the GlyR. In contrast, depolymerization of microfilaments should remove intergephyrin barriers and thus allow a tighter packing of GlyR within the subsynaptic lattice. Although the molecular mechanisms underlying our observations are far from clear, one might in addition speculate that in the absence of actin filaments, more gephyrin molecules could associate with tubulin than in their presence. Indeed, the cooperative nature of the gephyrin-tubulin interactions is compatible with variations of the binding stoichiometry (Kirsch et al., 1991).

The model discussed above implicates that the changes in cluster organization observed refer to truly postsynaptic structures. The latter are characterized by a close apposition to presynaptic nerve terminals, with high local concentrations of synaptic vesicle antigens and postsynaptic membrane specializations carrying neurotransmitter receptors. The results of our double-labeling experiments with mAbs $7 \mathrm{a}$ and $4 \mathrm{a}$ or $\mathrm{mAb} 7 \mathrm{a}$ and antiserum against synaptic vesicle antigens (Figs. 1, 4A) extend previous immunocytochemical (Nicola et al., 1992) and electrophysiological data (Ransom et al., 1977; Bormann et al., 1987) which indicate the formation of functional synapses in differentiating spinal cord cultures. In addition they demonstrate at the level of single optical sections that most gephyrin/GlyR clusters develop close contacts with presynaptic terminals within 10 $\mathrm{d}$ of in vitro development. Therefore, the altered spatial organization of the gephyrin clusters induced by alkaloid treatment are likely to reflect changes in functional postsynaptic membrane specializations.

The studies on the gephyrin/GlyR complex described here find a parallel in investigations on the "submembrane machinery" (Froehner, 1991) of the neuromuscular and electrocyte junctions (reviewed in Cartaud and Changeux, 1993). There, the formation and maintenance of postsynaptic membrane areas exhibiting an at least 1000-fold higher density of nicotinic acetylcholine receptors (nAChR) than found extrasynaptically (Fer- 
tuck and Salpeter, 1974; Matthews-Bellinger and Salpeter, 1978) depends on extracellular as well as intracellular components (McMahan and Wallace, 1989; Froehner, 1991; Rupp et al., 1991). Among the intracellular components a peripheral $43 \mathrm{~K}$ nrotein that codistributes with postsynaptic nAChRs at vertebrate neuromuscular junctions and the electromotor synapse of Torpedo electric organ (Burden et al., 1983; Nghiem et al., 1983; Sealock et al., 1984; Bridgman et al., 1989) appears to play a key role in synaptogenesis (Froehner et al., 1990; Phillips et al., $1991 \mathrm{a}, \mathrm{b})$. Coexpression of the $43 \mathrm{~K}$ protein with $\mathrm{n} \Lambda \mathrm{ChRs}$ subunits in fibroblasts (Phillips et al., 1991a) or Xenopus oocytes (Froehner et al., 1990) has been shown to cause nAChR clustering in the plasma membrane. Also, in vitro this polypeptide binds actin (Walker et al., 1984), but attempts to colocalize the $43 \mathrm{~K}$ protein with actin filaments in cultured rat myotubes and Torpedo electrocytes have produced controversial data (Bloch, 1986; LaRochcllc et al., 1990). Recent ultrastructural data have revealed the existence of cold-stable acetylated microtubules beneath the nAChR-rich membrane domains of the motor end plate (Jasmin et al., 1991). Microtubules thus may have a general role in the spatial organization of synaptic neurotransmitter receptors.

In conclusion, the data reported in this study suggest that the GlyR-associated protein gephyrin mediates postsynaptic receptor clustering by a complex interaction with different components of the cytoskeleton. Similar membrane protein-cytoskeleton linker proteins may also contribute to the localization of other channel proteins in specialized subdomains of the neuronal plasma membrane, for example, at the axonal nodes of Ranvier (Kordeli et al., 1990). Consistent with this view, the properties of voltage-gated potassium channels expressed in Xenopus oocytes have recently been reported to depend on the integrity of the cytoskeleton (Honoré et al., 1992).

\section{References}

Altschuler RA, Betz H, Parakkal M, Reeks K, Wenthold R (1986) Identification of glycinergic synapses in the cochlear nucleus through immunocytochemical localization of the postsynaptic receptor. Brain Res 369:316-320.

Bassell GJ, Singer RH, Kosik KS (1994) Association of poly(A) mRNA with microtubules in cultured neurons. Neuron 12:571-582.

Becker C-M, Hoch W, Betz II (1989) Sensitive immunoassay shows selective association of peripheral and integral membrane proteins of the inhibitory glycine receptor complex. J Neurochem 53:124-131.

Bencherif M, Lukas RJ (1993) Cytochalasin modulation of nicotinic cholinergic receptor expression and muscarinic receptor function in human TE671/RD cells: a possible functional role of the cytoskeleton. J Neurochem 61:852-864.

Bloch RJ (1986) Actin at receptor-rich domains of isolated acetylcholine receptor clusters. J Cell Biol 102:1447-1458.

Bormann J, Hamill OP, Sakmann B (1987) Mechanism of anion permeation through channels gated by glycine and $\gamma$-aminobutyric acid in mouse cultured spinal neurones. J Physiol (Lond) 385:243-286.

Bridgman PC, Carr C, Pedersen SE, Cohen JB (1989) Visualization of the cytoplasmic surface of Torpedo postsynaptic membrane by frecze-ctch and immunoclcctron microscopy. J Cell Biol 105:18291846.

Burden SJ, De Palma RL, Gottesman GS (1983) Crosslinking of proteins in acetylcholine receptor-rich membranes: association between the $\beta$-subunit and the $43 \mathrm{kD}$ subsynaptic protein. Cell 35:687-692.

Cartaud J, Changeux JP (1993) Post-transcriptional compartmentalization of acetylcholine receptor biosynthesis in the subneural domain of muscle and electrocyte junctions. Eur J Neurosci 5:191-202.

Fan JH, Mansfield SG, Redmond T (1993) The organization of F-actin and microtubules in growth cones exposed to a brain-derived collapsing factor. J Cell Biol 121:867-878.

Fentie IH, Roisen FJ (1993) The effects of cytoskeletal altering agents on the surface topography of GM1 in neuro-2A neuroblastoma cell membranes. J Neurocytol 22:-506.
Fertuck HC, Salpcter MM (1974) Localization of acetylcholine receptor by ${ }^{125}$ I-labeled $\alpha$ bungarotoxin binding at mouse motor endplates. Proc Natl Acad Sci USA 71:1376-1378.

Fletcher TL, Cameron P, De Camilli P, Banker G (1991) The distribution of synapsin I and synaptophysin in hippocampal neurons developing in culture. J Neurosci 11:1617-1628.

Froehner S (1991) The submembrane machinery of the nicotinic acetylcholine receptor clustering. J Cell Biol 114:1-7.

Froehner SC, Luetje CW, Scotland PB, Patrick J (1990) The postsynaptic $43 \mathrm{~K}$ protein clusters muscle nicotinic acetylcholine receptors in Xenopus oocytes. Neuron 5:403-410.

Hirokawa N (1991) Postsynaptic cytoplasm. In: The neuronal cytoskeleton (Burgoyne RD, ed), pp 59-74. New York: Wiley-Liss.

Hoch W, Betz H, Becker C-M (1990) Primary cultures of mouse spinal cord express the neonatal isoform of the inhibitory glycinte receptor. Neuron 3:339-348.

Honoré E, Attali B, Romey G, Lesage F, Barhanin J, Lazdunski M (1992) Different types of $\mathrm{K}^{+}$channel current are generated by different levels of a single mRNA. EMBO J 11:2465-2471.

Jasmin BJ, Changeux J-P, Cartaud J (1991) Compartmentalization of cold stable and acetylated microtubules in subsynaptic domains of chick skeletal muscle fibers. Nature 344:673-675.

Kirsch J, Ret7. H (1993) Widespread expression of gephyrin, a putative receptor-tubulin linker protein, in rat brain. Brain Res 621:301-310.

Kirsch J, Zutra A, Littauer UZ (1990) Characterization and intracellular distribution of microtubulc-associated protein 2 in differentiating human neuroblastoma cells. J Neurochem 55:1031-1041.

Kirsch J, Langosch D, Prior P, Littauer UZ, Schmitt B, Betz H (1991) The $93-\mathrm{kDa}$ glycine receptor-associated protein binds to tubulin. J Biol Chem 266:22242-22245.

Kirsch J, Malosio M-L, Wolters I, Betz H (1993a) Distribution of gephyrin transcripts in the adult and developing rat brain. Eur J Neurosci 5:1109-1117.

Kirsch J, Wolters I, Triller A, Betz H (1993h) Gephyrin antisense oligonucleotides prevent glycine receptor clustering in spinal neurons. Nature 366:745-748.

Knaus P, Betz H, Rehm H (1986) Expression of synaptophysin during postnatal development of the mouse brain. J Neurochem 47:13021304.

Knaus P, Marqueze-Pouey B, Scherer H, Betz H (1990) Synaptoporin, a novel putative channel protein of synaptic vesicles. Neuron 5:453462.

Kordeli E, Davis J, Trapp B, Bennett V (1990) An isoform of ankyrin is localized at the node of Ranvier in myelinated axons of central and peripheral nerves. J Cell Biol 110:1341-1352.

LaRochelle WJ, Witzemann V, Fiedler W, Froehner SC (1990) Developmental expression of the $43 \mathrm{~K}$ and $58 \mathrm{~K}$ postsynaptic membrane proteins and nicotinic acetylcholine receptors in Torpedo electrocytes. J Neurosci 10:3460-3467.

Malosio M-L, Marqueze-Pouey B, Kuhse J, Betz H (1991) Widespread cxpression of glycine receptor subunit mRNAs in the adult and developing brain. EMBO J 10:2401-2409.

Matthews-Bellinger J, Salpeter MM (1978) Distribution of acetylcholine receptors at frog neuromuscular junctions with a discussion of some physiological implications. J Physiol (Lond) 279:197-213.

McMahan UJ, Wallace BG (1989) Molecules in basal lamina that direct the formation of synaptic specializations at neuromuscular junctions. Dev Neurosci 11:227-247.

Meade LB, Topp KS (1994) Microtubule polarity in the peripheral processes of trigeminal ganglion cells: relevance for the retrograde transport of herpes simplex virus. J Neurosci 14:318-325.

Meyer G, Kirsch J, Ramming M, Grünert U, Betz H, Langosch D (1994) Glycine receptor $\beta$ subunit binds to the peripheral membrane protein gephyrin. Soc Neurosci Abstr 20:1124.

Miranda AF, Godman GC, Deitch AD, Tanenbaum SW (1974) Action of cytochalasin D on cells of established lines. J Cell Biol 61:481500 .

Nghiem HO, Cartaud J, Dubreuil C, Kordeli E, Buttin G, Changeux J-P (1983) Production and characterization of a monoclonal antibody directed against the 43,000-dalton $v_{1}$ polypeptide from Torpedo marmorata electric organ. Proc Natl Acad Sci USA 80:6403-6407.

Nicola M-A, Becker C-M, Triller A (1992) Development of glycine receptor alpha subunit in cultivated rat spinal neurons: an immunocytochemical study. Neurosci Lett 138:173-178.

Pfeiffer F, Graham D, Betz H (1982) Purification by affinity chroma- 
tography of the glycine receptor of rat spinal cord. J Biol Chem 257 : 9389-9393.

Pfeiffer F, Simler R, Grenningloh G, Betz H (1984) Monoclonal antibodies and peptide mapping reveal structural similarities between the subunits of the glycine receptor of rat spinal cord. Proc Natl Acad Sci USA 81:7224-7227.

Phillips WD, Kopta C, Blount P, Gardner PD, Steinbach JH, Merlie JP (1991a) ACh receptor-rich membrane domains organized in fibroblasts by recombinant 43-kilodalton protein. Science 251:568-570

Phillips WD, Maimone MM, Merlie JP (1991b) Mutagenesis of the 43 $\mathrm{kD}$ postsynaptic protein defines domains involved in plasma membrane targeting and AChR clustering. J Biol Chem 115:1713-1723.

Prior P, Schmitt B, Grenningloh G, Pribilla I, Multhaup G, Beyreuther K, Maulet Y, Werner P, Langosch D, Kirsch J, Betz H (1992) Primary structure and alternative splice variants of gephyrin, a putative glycine receptor-tubulin linker protein. Neuron 8:1161-1170.

Ransom BR, Christian CN, Bullock PN, Nelson PG (1977) Mouse spinal cord in cell culture: II. synaptic activity and circuit behavior. I Physiol (Lond) 40:1151-1162.

Rosenmund C, Westbrook GL (1993) Calcium-induced actin depolymerization reduces NMDA channel activity. Neuron 10:805-814.

Rupp F, Payan DG, Magill-Solc C, Cowan DM, Scheller RH (1991) Structure and expression of rat agrin. Neuron 6:811-823.

Sassoè-Pognetto M, Kirsch J, Grünert U, Greferath U, Fritschy JM, Möhler H, Betz H, Wässle H (1995) Colocalization of gephyrin and $\mathrm{GABA}_{\mathrm{A}}$-receptor subunits in the rat retina. I Comp Neurnl, in press.
Schiff PB, Horwitz SB (1980) Taxol stabilizes microtubules in mouse fibroblast cells. Proc Natl Acad Sci USA 77:1561-1565.

Schmitt B, Knaus P, Becker C-M, Betz H (1987) The Mr 93,000 polypeptide of the postsynaptic glycine receptor is a peripheral membrane protein. Biochemistry 26:805-811.

Schröder S, Hoch W, Becker C-M, Grenningloh G, Betz H (1991) Mapping of antigenic epitopes on the $\alpha 1$ subunit of the inhibitory glycine receptur. Biochenistry 30:42-47.

Sealock R, Wray B, Froehner SC (1984) Ultrastructural localization of the $M_{r} 43,000$ protein and the acetylcholine receptor in Torpedo postsynaptic membrane using monoclonal antibodies. J Cell Biol 98: 2239-2244.

Seitanidou T, Nicola M-A, Triller A, Korn H (1992) Partial glycinergic denervation induces transient changes in the distribution of a glycine receptor-associated protein in a central neuron. J Neurosci 12:116131.

Triller A, Cluzeaud F, Pfeiffer F, Betz H, Korn H (1985) Distribution of glycine receptors at central synapses: an immunoelectron microscopy study. J Cell Biol 101:683-688.

Triller A, Cluzeaud F, Korn H (1987) Gamma-aminobutyric acid-containing terminals can be apposed to glycine receptors at central synapses. J Cell Biol 104:947-956.

Walker JH, Boustead CM, Witzemann V (1984) The 43K protein, $v_{1}$, associated with acetylcholine receptor containing membrane fragments is an actin binding protein. EMBO J 3:2287-2296.

Wulf E, Debonen A, Bautz FA, Faulstich H, Wieland T (1979) Fluorescent phallotoxin, a tool for the visualisation of cellular actin. Proc Natl Acad Sci USA 76:4-4502. 